\title{
Response of Summer Green Gram [Vigna radiata (L.) Wilczek] Varieties to Different Nutrient Management under South Gujarat Condition
}

\author{
Kartik H. Patel, K. A. Shah* and H. B. Patel \\ Department of Agronomy, Krishi Vigyan Kendra, Navsari Agricultural University, \\ Eru Char Rasta, Navsari 396 450, Gujarat, India \\ *Corresponding author
}

\section{A B S T R A C T}

\begin{abstract}
An experiment was conducted during summer season of 2017 at the college farm, Navsari Agricultural University, Navsari to study the "Production potential of green gram [Vigna radiata (L.) Wilczek] varieties with different nutrient management under south Gujarat condition". The soil of the experimental field was clayey in texture having medium to poor drainage, low in available nitrogen and organic carbon, medium in available phosphorus, potassium and sulphur. Total eighteen treatment combinations consisting of three varieties viz., NKM-15-12 $\left(\mathrm{V}_{1}\right)$, GAM-5 $\left(\mathrm{V}_{2}\right)$ and Meha $\left(\mathrm{V}_{3}\right)$ and six levels of nutrient management practices viz., $\mathrm{T}_{1}(75 \%$ RDF), $T_{2}\left(100 \%\right.$ RDF), $T_{3}\left(75 \%\right.$ RDF + $10 \mathrm{~kg}$ Sulphur/ha), $T_{4}\left(75 \% \mathrm{RDF}+20 \mathrm{~kg}\right.$ Sulphur/ha), $\mathrm{T}_{5}(100 \% \mathrm{RDF}+$ $10 \mathrm{~kg} \mathrm{Sulphur} / \mathrm{ha})$ and $\mathrm{T}_{6}(100 \% \mathrm{RDF}+20 \mathrm{~kg}$ Sulphur/ha) were tested in factorial randomized block design with three replications. Variety NKM-15-12 (GM-6) recorded significantly higher value of plant height at 60 DAS and at harvest, number of seeds per pod, length of pod and test weight as compared to variety GA-5, Varieties Meha and GAM-5 being at par but registered remarkably higher number of pods per plant over NKM-15-12. Significantly the higher seed $(1186 \mathrm{~kg} / \mathrm{ha})$, haulm $(2430 \mathrm{~kg} / \mathrm{ha})$ and protein yield $(226.20 \mathrm{~kg} / \mathrm{ha})$ of greengram were produced under the variety NKM-15-12 as compared to other varieties, respectively. Numerically higher protein content of greengram was registered under the variety Meha. The maximum gross realization of Rs 77264/ha, net realization of Rs 52021/ha and the BCR value of 3.06 was also observed under the variety NKM15-12. Plant height at harvest, number of pods per plant, number of seeds per pod and test weight were found to be remarkably higher under the application of $100 \%$ RDF along with $20 \mathrm{~kg} \mathrm{~S} / \mathrm{ha}$ as compared to $75 \% \mathrm{RDF}$. Significantly the highest seed $(1184 \mathrm{~kg} / \mathrm{ha})$, haulm $(2394 \mathrm{~kg} / \mathrm{ha})$ and protein yield $(219.30 \mathrm{~kg} / \mathrm{ha})$ of greengram were produced due to the application of same treatment of $100 \% \mathrm{RDF}$ along with $20 \mathrm{~kg}$ S/ha over control, which was at par with $100 \% \mathrm{RDF}$ with $10 \mathrm{~kg} \mathrm{~S} / \mathrm{ha}$ and $75 \% \mathrm{RDF}$ with $20 \mathrm{~kg} \mathrm{~S} / \mathrm{ha}$. The numerically higher protein content was found under the same treatment. The maximum gross realization of Rs $77028 \mathrm{ha}^{-1}$, net realization of Rs $49381 \mathrm{ha}^{-1}$ and BCR value of 2.79 were secured under the application of $100 \% \mathrm{RDF}$ along with $20 \mathrm{~kg} \mathrm{~S} / \mathrm{ha}$.
\end{abstract}

\section{Introduction}

Greengram [Vigna radiata (L.) Wilczek] is one of the most ancient and extensively grown leguminous crops of India. It is a native of India and Central Asia and commonly known as mung bean. It is the third important pulse crop after chickpea and pigeon pea, cultivated throughout India for its multipurpose uses as vegetable, pulse, fodder and green manure crop. Its seed is more palatable, nutritive, digestible and nonflatulent than other pulses grown in world. The pulses are known to improve the physical characteristics of soil through tap root system which opens the soil in to the deeper strata 
and their ability to use atmospheric nitrogen through biological nitrogen fixation which is economically sound and environmentally acceptable. Pulses are drought resistant and prevent soil erosion due to their deep root and good ground covers, because of these good characters, pulses are called as "Marvel of Nature". Pulses can also be referred to as "mini fertilizer factory", as they fix atmospheric nitrogen through symbiosis.

India is the largest producer $(25 \%$ of global production), consumer $(27 \%$ of world consumption) and importer (14\%) of pulses in the world. Pulses production in India has not kept up with growth in demand calling for import to the tune of 2.0 to 4.0 million tonnes (Raj et al., 2013). Even though pulses production increased significantly during the last decade but continuing the rapid growth is a challenge for researchers, extension agencies and policy makers to fulfil the domestic demand.

A variety can express its full yield potential under favourable managemental conditions and optimum level of required inputs. Varietals response to graded levels of fertilizer and sulphur is of great importance since varieties differ in their growth and developmental behaviour.

Greengram gives low seed yield and poor growth performance mainly due to poor management and low soil fertility. Nitrogen due to leaching and volatilization and phosphorus due to fixation may not be available adequately at flowering and pod formation stages of crop and result in shading of flowers and pods. The crop needs more nitrogen at the reproductive phase, and the nutrient uptake after flowering either becomes slow or stops due to inactivation of roots. The optimum supply of nitrogen and phosphorus influenced the growth and yield of greengram (Rathod and Gawande, 2012).
After phosphorus, sulphur nutrition has been found to be major limiting factor in greengram production. sulphur is now recognized as major plant nutrient, along with nitrogen $(\mathrm{N})$, phosphorus $(\mathrm{P})$ and potassium $(\mathrm{K})$. Sulphur deficiency is becoming more critical with each passing year which is severely restricting crop yield, quality, nutrient use efficiency and economic returns of millions of farms. Like any essential nutrient, sulphur also has certain specific functions to perform in the plant. Thus, sulphur deficiencies can only be corrected by the application of sulphur fertilizer (Tandon and Messick, 2007). An application of sulphur has a synergistic effect on productivity of crops.

Considering the above facts and very less work done in south Gujarat region the experiment has been planned to study the "Production potential of greengram [Vigna radiata (L.) Wilczek] varieties with different nutrient management under south Gujarat condition" during summer season of 2017 at College Farm, N. M. College of Agriculture, Navsari Agricultural University, Navsari.

\section{Materials and Methods}

Field experiment was conducted in summer season of 2017 at the college farm, Navsari Agricultural University, Navsari, Gujarat. Total eighteen treatment combinations comprising of three varieties viz., NKM-15-12 $\left(\mathrm{V}_{1}\right)$, GAM-5 $\left(\mathrm{V}_{2}\right)$ and Meha $\left(\mathrm{V}_{3}\right)$ and six levels of nutrient management practices viz., $\mathrm{T}_{1}$ (75\% RDF), $\mathrm{T}_{2}$ (100\% RDF), $\mathrm{T}_{3}$ (75\% RDF $+10 \mathrm{~kg}$ sulphur/ha), $\mathrm{T}_{4}(75 \% \mathrm{RDF}+20 \mathrm{~kg}$ sulphur/ha), $\mathrm{T}_{5}(100 \% \mathrm{RDF}+10 \mathrm{~kg}$ sulphur/ha) and $\mathrm{T}_{6}(100 \% \mathrm{RDF}+20 \mathrm{~kg}$ sulphur/ha) were evaluated in factorial randomized block design with three replications. The soil of the experimental field was clayey in texture having medium to poor drainage, soil $\mathrm{pH} 7.60$, EC $0.57 \mathrm{dS} / \mathrm{m}$ and 
organic carbon content $0.36 \%$. The soil is low in available nitrogen (184 kg/ha) and medium in available phosphorus (38.40 $\mathrm{kg} / \mathrm{ha})$, potassium $(236.20 \mathrm{~kg} / \mathrm{ha})$ and sulphur (4.22 ppm) were determined by Kjeldahl's method, Olsen's method, Flame photometric method and Turbidiometric method, respectively. Greengram varieties NKM-15-12 (GM-6), GAM-5 and Meha seeds were sown at $30 \mathrm{~cm}$ $\mathrm{x} 10 \mathrm{~cm}$ spacing.

The entire dose of fertilizer was applied as per the treatments. Urea, DAP and gypsum were taken as fertilizer sources for $\mathrm{N}, \mathrm{P}$ and $\mathrm{S}$, respectively. All other operation was performed as per recommendations of the crops. The data on seed and haulm yields as well as protein content were recorded under various treatments after harvest of crop. The results were analysis statistically to draw suitable interference as per the standard ANOVA techniques suggested by Gomez and Gomez (1984).

\section{Results and Discussion}

\section{Effect of variety}

The different varieties shows their significant difference on all most all growth and yield attributes as well as yield parameters (Table 1 $\&$ 2). Number of branches per plant did not significantly influenced due to different varieties. Significantly the taller plant height at 60 DAS $(47.50 \mathrm{~cm})$ and at harvest $(52.76$ $\mathrm{cm})$ were recorded under the variety NKM15-12 over variety GAM-5, which was at par with variety Meha at 60 DAS $(47.41 \mathrm{~cm})$ and at harvest $(52.44 \mathrm{~cm})$. Significant difference in plant height was observed due to their genetically different growth habit. These results are in accordance with the findings of Rathod and Gawande (2012), Patel et al., (2013b), Gorade et al., (2014) and Patel et al., (2016b). Non-significantly, but numerically higher value of number of branches per plant at harvest (4.13) registered under the variety NKM-15-12 followed by GAM-5. These findings are substantiated with those reported by Dash and Rautaray (2017).

The variation in the yield attributing parameters like number of pods per plant, number of seeds per pod, length of the pod and test weight were significantly influenced due to different varieties. The yield attributing parameters viz., number of seeds per pod (11.04), pod length $(9.71 \mathrm{~cm})$ and test weight $(53.91 \mathrm{~g})$ were found significantly superior under the variety NKM-15-12 ( $\left.\mathrm{V}_{1}\right)$ over varieties GAM-5 $\left(\mathrm{V}_{2}\right)$ and Meha $\left(\mathrm{V}_{3}\right)$.

However, remarkably the higher number of pods per plant (41.06) was recorded under the variety Meha over NKM-15-12, which was at par with variety GAM-5 (39.47). The percentage increase in the number of seeds per pod, length of pod and test weight were up to the tune of 23.21, 36.95 and 32.94 per cent under the variety NKM-15-12 over Meha, respectivaly. This difference in yield attributing characters among the different varieties might be due to genetic constitution of these varieties. The present findings are within the close vicinity of those reported by Gangwar et al., (2013), Gorade et al., (2014), Jadhav et al., (2014) and Patel et al., (2016b).

It is evident from the results presented in Table 2 that there was a significant difference in seed and haulm yields of greengram due to different varieties. The variety NKM-15-12 $\left(\mathrm{V}_{1}\right)$ produced significantly the higher seed (1186 kg/ha) and haulm yields (2430 kg/ha) as compared to varieties GAM-5 $\left(\mathrm{V}_{2}\right)$ and Meha $\left(\mathrm{V}_{3}\right)$. The lowest seed $(974 \mathrm{~kg} / \mathrm{ha})$ and haulm yield $(2145 \mathrm{~kg} / \mathrm{ha})$ of greengram were registered under the variety Meha $\left(\mathrm{V}_{3}\right)$. The magnitude of increased in green gram seed yield of 21.76 per cent and haulm yield of 13.28 per cent were registered under the variety NKM-15-12 over variety Meha. 
This might be due to a variety of crop differed in its genetic built up along with almost all the yield attributing characters were found remarkably higher under the same variety, hence resulted in the higher yield. The above findings are in complete agreement with earlier work of Rathod and Gawande (2012), Shelke et al., (2012), Patel et al., (2013b), Gorade et al., (2014), Patel et al., (2016b), Dash and Rautaray (2017) and Puniya et al., (2017).

The protein content of grrengram seed did not affected significantly due to different varieties. The variety Mean recorded non significantly by numerically higher values of protein content $(22.90 \%)$ followed by GAM-5 $(22.78 \%)$ However, protein yield was influenced significantly due to the different varieties.. Variety NKM-15-12 was recorded significantly the highest protein yield (267.18 $\mathrm{kg} / \mathrm{ha}$ ) as compared to variety GAM-5 $(247.50 \mathrm{~kg} / \mathrm{ha})$ and Meha $(222.78 \mathrm{~kg} / \mathrm{ha})$. This difference in protein yield under different varieties occurs due to higher seed yield was observed under the same variety. Similar types of results were also found by Gangwar et al., (2013) and Singh and Singh (2014).

The variation in gross realization, net realization and benefit cost ratio were observed due to use of different varieties. Among different varieties, $\mathrm{V}_{1}$ (NKM-15-12) secured maximum gross realization of Rs 77264/ha, net realization of Rs 52021/ha and BCR of 3.06. While the lowest gross realization of Rs 63824/ha, net realization of Rs 38581/ha and BCR of 2.53 were registered under the variety $\mathrm{V}_{3}$ (Meha). This might be due to the highest grain and haulm yields were recorded under same variety $\left(\mathrm{V}_{1}\right)$ as compared to rest of the varieties. The results confirm the findings of Shelke et al., (2012), Patel et al., (2013b), Jadhav et al., (2014), Singh and Singh (2014), Dash and Rautaray (2017) and Puniya et al., (2017).

\section{Effect of nutrient management practices}

Effect of various nutrient management treatments did not manifest their significant variation on growth parameters like plant height at 60 DAS and number of branches per plant at harvest (Table 1). Non significantly but numerically higher value of plant height at 60 DAS $(47.97 \mathrm{~cm})$ and number of branches per plant (4.16) at harvest were recorded with the treatment of $100 \%$ RDF with $20 \mathrm{~kg}$ S/ha $\left(\mathrm{T}_{6}\right)$ followed by treatment of $75 \% \mathrm{RDF}$ with $20 \mathrm{~kg} \mathrm{~S} / \mathrm{ha}\left(\mathrm{T}_{5}\right)$. An application of $100 \% \mathrm{RDF}$ $+20 \mathrm{~kg} \mathrm{~S} / \mathrm{ha}\left(\mathrm{T}_{6}\right)$ produced significantly taller plant height of greengram at harvest $(53.75$ $\mathrm{cm}$ ) as compared to 75 and $100 \%$ RDF, which was at par with treatment $\mathrm{T}_{5}(52.73 \mathrm{~cm}), \mathrm{T}_{4}$ $(52.08 \mathrm{~cm})$ and $\mathrm{T}_{3}(51.28 \mathrm{~cm})$. This might be due to the fulfillment of major nutrient requirements along with sulphur, being a fourth major nutrient, might have play an important physiological role by enhancing the cell division and multiplication, elongation and chlorophyll biosynthesis, which turn in to better plant height. Almost similar findings were also reported by Patel et al., (2013a), Kumar et al., (2015), Srinivasulu et al., (2016) and Patel et al., (2018).

Almost all the yield attributes such as number of pods per plant, number of seeds per pod and test weight (Table 1) were influenced remarkably by different nutrient management practices. Significantly the higher number of pods per plant (41.23), number of seeds per pod (10.82) and test weight (49.88 g) were produced due to application of $100 \% \mathrm{RDF}+$ $20 \mathrm{~kg} \mathrm{~S} / \mathrm{ha}\left(\mathrm{T}_{6}\right)$ over rest of the treatments, ecxept the treatment of $100 \%$ RDF with sulphur @ $10 \mathrm{~kg} / \mathrm{ha}\left(\mathrm{T}_{5}\right)$ and $75 \%$ RDF with $20 \mathrm{~kg} \mathrm{~S} / \mathrm{ha}\left(\mathrm{T}_{4}\right)$. Non significantly, but numerically higher length of pod $(8.61 \mathrm{~cm})$ of greengram was also found under the same treatment $\left(\mathrm{T}_{6}\right)$. All yield attributing character found remarkably lower under the treatment of $75 \%$ RDF. The increase in yield attributes 
under sulphur fertilization along with major nutrient helps in improve overall nutritional environment in the rhizosphere as well as availability of the nutrients for plant, which turn in to enhanced the plant metabolism and photosynthetic activity resulting in to better growth and yield attributes of plant. Positive responses in terms of yield attributes due to application of major nutrient along with sulphur have been also reported by Thesiya et al., (2013), Gorade et al., (2014), Kokani et al., (2015) and Rani et al., (2016).

The variation in seed and haulm yield of green gram was significantly differed due to various treatments of nutrient management practices (Table 2). The seed (1184 kg/ha) and haulm yield $(2394 \mathrm{~kg} / \mathrm{ha})$ were produced significantly higher under the treatment $\mathrm{T}_{6}$ $(100 \% \mathrm{RDF}+20 \mathrm{~kg}$ sulphur/ha) over treatment $\mathrm{T}_{1}$, but it was at par with treatment $\mathrm{T}_{5}\left(100 \% \mathrm{RDF}+10 \mathrm{~kg}\right.$ sulphur/ha) and $\mathrm{T}_{4}$ (75\% RDF + $20 \mathrm{~kg}$ sulphur/ha).

An application of $75 \%$ RDF registered the lowest seed (964 kg/ha) and haulm (2108 $\mathrm{kg} / \mathrm{ha}$ ) yield. The percent increasing in the seed and haulm yield of 22.82 and 13.56 per cent were noticed due to the treatment $\mathrm{T}_{6}$ over treatment $T_{1}$. Improvement in the yield might have resulted from adequate supply of photosynthate from source to sink due to adequate supply of major nutrients under higher level of fertilizer and along with sulphur helps in significant improvements in growth and yield attributes. The present results closely resembled with those of Patel et al., (2013b), Bairwa et al., (2014), Kumar et al., (2015), Srinivasulu et al., (2015), Dharwe et al., (2018) and Patel et al., (2018).

Table.1 Effects of variety and nutrient management practices on growth and yield attributes of greengram

\begin{tabular}{|c|c|c|c|c|c|c|c|}
\hline \multirow[t]{2}{*}{ Treatment } & \multicolumn{2}{|c|}{$\begin{array}{l}\text { Plant height } \\
(\mathrm{cm})\end{array}$} & \multirow{2}{*}{$\begin{array}{c}\text { Number } \\
\text { of } \\
\text { branches } \\
\text { /plant }\end{array}$} & \multirow{2}{*}{$\begin{array}{c}\text { Numbe } \\
\mathbf{r} \text { of } \\
\text { pods/ } \\
\text { plant }\end{array}$} & \multirow{2}{*}{$\begin{array}{c}\text { Numbe } \\
\text { r of } \\
\text { seed/ } \\
\text { pod }\end{array}$} & \multirow{2}{*}{$\begin{array}{c}\text { Length } \\
\text { of } \\
\text { pod } \\
(\mathrm{cm})\end{array}$} & \multirow{2}{*}{$\begin{array}{c}\text { Test } \\
\text { weight } \\
\text { (g) }\end{array}$} \\
\hline & $\begin{array}{c}60 \\
\text { DAS }\end{array}$ & $\begin{array}{c}\text { At } \\
\text { harvest }\end{array}$ & & & & & \\
\hline \multicolumn{8}{|l|}{ Variety (V) } \\
\hline$V_{1}:$ NKM-15-12 & 47.50 & 52.76 & 4.13 & 36.20 & 11.04 & 9.71 & 53.91 \\
\hline $\mathrm{V}_{2}:$ GAM-5 & 43.83 & 49.03 & 3.86 & 39.47 & 10.21 & 8.07 & 49.94 \\
\hline$V_{3}:$ Meha & 47.41 & 52.44 & 3.82 & 41.06 & 8.96 & 7.09 & 40.55 \\
\hline S. Em. \pm & 0.77 & 0.81 & 0.11 & 0.71 & 0.20 & 0.18 & 0.59 \\
\hline C. D. $(P=0.05)$ & 2.23 & 2.34 & NS & 2.05 & 0.59 & 0.53 & 1.70 \\
\hline \multicolumn{8}{|c|}{ Nutrient Management Practices (T) } \\
\hline $\mathrm{T}_{1}: \mathbf{7 5 \%} \mathrm{RDF}$ & 44.00 & 48.68 & 3.82 & 36.51 & 9.51 & 8.02 & 46.05 \\
\hline $\mathrm{T}_{2}: 100 \% \mathrm{RDF}$ & 45.66 & 49.88 & 3.87 & 38.24 & 9.76 & 8.28 & 47.50 \\
\hline$T_{3}: T_{1}+10 \mathrm{~kg} \mathrm{Sulphur} / \mathrm{ha}$ & 45.82 & 51.28 & 3.83 & 38.07 & 9.84 & 8.16 & 47.44 \\
\hline$T_{4}: T_{1}+20 \mathrm{~kg} \mathrm{Sulphur/ha}$ & 46.65 & 52.08 & 3.94 & 39.82 & 10.23 & 8.35 & 48.94 \\
\hline$T_{5}: T_{2}+10 \mathrm{~kg} \mathrm{Sulphur} / \mathrm{ha}$ & 47.37 & 52.73 & 4.02 & 39.62 & 10.27 & 8.37 & 49.00 \\
\hline$T_{6}: T_{2}+20 \mathrm{~kg}$ Sulphur/ha & 47.97 & 53.75 & 4.16 & 41.23 & 10.82 & 8.61 & 49.88 \\
\hline S. Em. \pm & 1.09 & 1.15 & 0.16 & 1.01 & 0.29 & 0.26 & 0.83 \\
\hline C. D. $(P=0.05)$ & NS & 3.30 & NS & 2.91 & 0.84 & NS & 2.40 \\
\hline $\mathrm{CV} \%$ & 7.13 & 6.71 & 12.84 & 7.81 & 8.75 & 9.60 & 5.22 \\
\hline
\end{tabular}


Table.2 Effects of variety and nutrient management practices on yield, quality parameters and economics of greengram

\begin{tabular}{|c|c|c|c|c|c|c|c|c|}
\hline Treatment & $\begin{array}{c}\text { Seed } \\
\text { yield } \\
\text { (kg/ha) }\end{array}$ & $\begin{array}{l}\text { Haulm } \\
\text { yield } \\
\text { (kg/ha) }\end{array}$ & $\begin{array}{l}\text { Protein } \\
\text { content } \\
(\%)\end{array}$ & $\begin{array}{c}\text { Protein } \\
\text { yield } \\
\text { (kg/ha) }\end{array}$ & $\begin{array}{c}\text { Cost of } \\
\text { production } \\
\text { (Rs/ha) }\end{array}$ & $\begin{array}{l}\text { Gross } \\
\text { return } \\
\text { (Rs/ha) }\end{array}$ & $\begin{array}{c}\text { Net } \\
\text { return } \\
\text { (Rs/ha) }\end{array}$ & BCR \\
\hline \multicolumn{9}{|l|}{ Variety (V) } \\
\hline$V_{1}:$ NKM-15-12 & 1186 & 2430 & 22.49 & 267.18 & 25243 & 77264 & 52021 & 3.06 \\
\hline $\mathrm{V}_{2}:$ GAM-5 & 1084 & 2210 & 22.78 & 247.50 & 25243 & 70589 & 45346 & 2.80 \\
\hline$V_{3}:$ Meha & 974 & 2145 & 22.90 & 222.78 & 25243 & 63824 & 38581 & 2.53 \\
\hline S. Em. \pm & 22.76 & 35.34 & 0.28 & 5.75 & - & - & - & - \\
\hline C. D. $(P=0.05)$ & 65.48 & 101.66 & NS & 16.54 & - & - & - & - \\
\hline \multicolumn{9}{|c|}{ Nutrient Management Practices (T) } \\
\hline $\mathrm{T}_{1}: 75 \% \mathrm{RDF}$ & 964 & 2108 & 22.00 & 212.23 & 26901 & 63115 & 36214 & 2.35 \\
\hline $\mathrm{T}_{2}: 100 \% \mathrm{RDF}$ & 1072 & 2149 & 22.79 & 244.18 & 27454 & 69708 & 42254 & 2.54 \\
\hline $\begin{array}{l}T_{3}: T_{1}+10 \mathrm{~kg} \\
\text { Sulphur/ha }\end{array}$ & 1033 & 2244 & 22.62 & 232.99 & 26998 & 67646 & 40648 & 2.51 \\
\hline $\begin{array}{l}\mathrm{T}_{4}: \mathrm{T}_{1}+20 \mathrm{~kg} \\
\text { Sulphur/ha }\end{array}$ & 1109 & 2326 & 22.86 & 253.52 & 27094 & 72384 & 45290 & 2.67 \\
\hline $\begin{array}{l}T_{5}: T_{2}+10 \mathrm{~kg} \\
\text { Sulphur/ha }\end{array}$ & 1126 & 2349 & 22.78 & 256.59 & 27550 & 73475 & 45925 & 2.67 \\
\hline $\begin{array}{l}T_{6}: T_{2}+20 \mathrm{~kg} \\
\text { Sulphur/ha }\end{array}$ & 1184 & 2394 & 23.29 & 275.41 & 27647 & 77028 & 49381 & 2.79 \\
\hline S. Em. \pm & 32.19 & 49.98 & 0.40 & 8.13 & - & - & - & - \\
\hline C. D. $(P=0.05)$ & 92.60 & 143.78 & NS & 23.39 & - & - & - & - \\
\hline CV\% & 8.93 & 6.63 & 5.41 & 9.93 & - & - & - & - \\
\hline
\end{tabular}

Application of different nutrient management practices did not exert any significant effect on protein content, but it found remarkable variation on protein yield (Table 2). Significantly the highest protein yield (275.41 $\mathrm{kg} / \mathrm{ha}$ ) was recorded due to the application of $100 \%$ RDF with sulphur @ $20 \mathrm{~kg} / \mathrm{ha}\left(\mathrm{T}_{6}\right)$ over other treatments, which was remained at par with treatment $\mathrm{T}_{5}$ and $\mathrm{T}_{4}$.

Similarly, protein content was found numerically higher under the same treatment. The improvement in protein yield might be due to higher seed yield of greengram couple with protein content under the treatment of 100\% RDF with sulphur@ 20 kg/ha. These finding are in agreement with the experimental results reported by Elamin and Madhavi (2015) and Patel et al., (2016a). A perusal of data presented in Table 2 revealed that application of $100 \%$ RDF with $20 \mathrm{~kg}$ $\mathrm{S} / \mathrm{ha}\left(\mathrm{T}_{6}\right)$ recorded maximum gross realization of Rs $77028 \mathrm{ha}^{-1}$, net realization of Rs 49381 $\mathrm{ha}^{-1}$ with BCR of 2.79, which was followed by gross realization of Rs $73475 \mathrm{ha}^{-1}$, net realization of Rs $45925 \mathrm{ha}^{-1}$ with BCR of 2.67 under treatment $\mathrm{T}_{5}$. The treatment of $75 \%$ RDF incurve the lowest gross realization of Rs 63115 ha $^{-1}$, net realization of Rs. 36214 ha $^{-}$ ${ }^{1}$ with BCR of 2.35. Similar views in direction of present finding were also expressed by Patel et al., (2013a), Patel et al., (2013b), Srinivasulu et al., (2015) and Patel et al., (2016a). 
On the basis of results obtained in the present investigation, following conclusions are made. NKM-15-12 (GM-6) is better variety of summer greengram for the south Gujarat condition over $c v$. GAM-5 and Meha. For getting more profitable yield as well as considering minimum input cost, summer greengram should be fertilized with $75 \% \mathrm{RDF}$ (15-30-00 NPK kg/ha) + $20 \mathrm{~kg} \mathrm{S/ha} \mathrm{through}$ gypsum under south Gujarat condition.

\section{References}

Bairwa, R. K., Nepalia, V., Balai, C. M., Jalwania, R. and Meena, H. P. 2014. Yield and nutrient uptake of summer greengram (Vigna radiata L.) under different levels of phosphorus and sulphur fertilizations. SAARC Journal of Agriculture, 12(1): 162-172.

Dash, S. R. and Rautaray, B. K. 2017. Growth parameters and yields of greenram varieties (Vigna radiata $\mathrm{L}$.) in east and south east coastal plain of Odisha, India. International Journal of Current Microbiology and Applied Sciences, 6(10): 1517-1510.

Dharwe, D. S., Dixit, H. S., Dotaniya, C. K., Mohbe, S. and Doutaniya, R. K. 2018. Influences of sulphur on the yield of summer greengram (Vigna radiata L.). Journal of Pharmacognosy and Phytochemistry, 7(2): 147-149.

Elamin, Y. A. and Madhavi, K. 2015. Residual effect of integrated nutrient management on growth and yield parameters of rabi chickpea (Cicer arietinum L.) under cropping system. American Journal of Scientific and Industrial Research, 6(5): 103-109.

Gangwar, A., Jadhav, T. A. and Sarvade, S. 2013. Productivity, nutrient removal and quality of urdbean varieties planted on different dates. Bioinfolet, 10(1A): 139-142.

Gomez K. A. and Gomez A. A. 1984.
Statistical Procedure for Agricultural Research. Jhon Wiely and Sons, New York, pp:139-264.

Gorade, V. N., Chavan, L. S., Jagtap, D. N. and Kolekar, A. B. 2014. Response of greengram (Vigna radiata L.) varieties to integrated nutrient management in summer season. Agriculture Science Digest, 34(1): 36-40.

Jadhav, P. B., Kamble, D. R., Jadhav, K. T. and Gadpale, D. L. 2014. Performance of black gram (Vigna mungo (L.) Hepper) varieties to different sowing dates. Advance Research Journal of Crop Improvement, 5(2): 166-171.

Kokani, J. M., Shah, K. A., Tandel, B. M. and Bhimani, G. J. 2015. Effect of FYM, phosphorus and sulphur on yield of sumeer blackgram and post-harvest nutrient status of soil. The Bioscan, 10(1): 379-383.

Kumar. D., Arvadiya, L. K., Usadadiya, V. P. and Patel, A. M. 2015. Growth and yield of chickpea (Cicer arietinum L.) as influenced by graded levels of fertilizers and bio fertilizers. The Bioscan, 10(1): 335-338.

Patel, A. K., Nath, T., Prajapati, A., Singh, V. K. and Pandey, K. 2018. Effect of doses and sources of sulphur on growth and yield of black gram (Vigna mungo L. Hepper) under rainfed condition of vindhyan soil. Journal of Pharmacognosy and Phytochemistry, pp: 91-94.

Patel, A. R., Patel, D. D., Patel, T. U. and Patel, H. M. 2016a. Nutrient management in summer green gram (Vigna radiata L.). International Journal of Applied and Pure Science and Agriculture, 2(2): 133-142.

Patel, H. R., Patel, H. F., Maheriya, V. D. and Dodia, I. N. 2013a. Response of kharif greengram (Vigna radiata $\mathrm{L}$. Wilczek) to sulphur and phosphorus fertilization with and without bio-fertilizer 
application. The Bioscan, 8(1): 149-152.

Patel, R. D., Chaudhari, D. D., Vaishali, M. P. S., Patel, K. G. and Tandel, B. B. 2013b. Response of different cultivars of greengram (Vigna radiata L. wilczek) to integrated nutrient management under south Gujarat condition. AGRES-An International $e$ Journal, 2(2): 132-142.

Patel, S. A., Chaudhari, P. P., Patel, A. M. and Chaudhari, G. K. 2016b. Response of greengram (Vigna radiata (L) wilczek) cultivars to integrated nutrient management. The Bioscan, 11(2): 11791181.

Puniya, R., Palsaniya, S., Chand, L., Sharma, A., Thakur, N. P. and Bazaya, B. R. 2017. Influence of sowing dates and varieties on the yield, heat use efficiency, energy utilization and economics of summer mungbean. Legume Research, pp: 1-7.

Raj, A. D., Yadav, V. and Rathod, J. H. 2013. Impact of front line demonstrations (FLD) on the yield of pulses. International Journal of Scientific and Research Publications, 3(9): 1-4.

Rani, M., Prakash, V. and Khan, K. 2016. Response of mungbean (Vigna radiata L. Wilczek) to phosphorus, sulphur and PSB during summer season. Agriculture Science Digest, 36(2): 146-148.

Rathod, S. L. and Gawande, M. B. 2012. Response of greengram varieties to different fertilizer grades. International Journal of Science and Research, 3(7):
1313-1315.

Shelke, A. V., Sonani, V. V., Gaikwad, V. P., Raskar, S. S. and Sawant, V. B. 2012. Effect of different fertility and biofertilizer levels on yield and economics of summer greengram. International Journal of Forestry and Crop Improvement, 3(2): 162-164.

Singh, H. and Singh, G. 2014. Response of mungbean varieties to sowing time and planting geometry. Journal of Food Legumes, 27(4): 347-349.

Srinivasulu, D. V., Solanki, R. M., Kumar, N. N., Bhanuprakash, M. and Vemaraju, A. 2016. Effect of irrigation based on IW/CPE ratio and sulphur levels on yield and quality of gram (Cicer arietinum L.). Legume Reserch, 39(4): 601-604.

Srinivasulu, D. V., Solanki, R. M., Radha Kumari, C. and Babu, V. S. 2015. Nutrient uptake, yield and protein content of chickpea (Cicer arietinum L.) as influenced by irrigation and sulphur levels in medium black soils. International Journal of Agricultural Sciences, 11(1): 54-58.

Thesiya, N. M., Chovatia, P. K. and Kikani, V. L. 2013. Effect of potassium and sulphur on growth and yield of black gram (Vigna mungo L. Hepper) under rainfed condition. Legume Research, 36(3): 255-258.

Tandon, H. L. S. and Messick, D. L. 2007. Practical of sulphur guide. The Sulphur Institute, Washington, D. C. pp: 1-2.

\section{How to cite this article:}

Kartik H. Patel, K. A. Shah and Patel. H. B. 2020. Response of Summer Green Gram [Vigna radiata (L.) Wilczek] Varieties to Different Nutrient Management under South Gujarat Condition. Int.J.Curr.Microbiol.App.Sci. 9(05): 1043-1050.

doi: https://doi.org/10.20546/ijcmas.2020.905.114 